\title{
Tetraspore germination in Catenella nipae Zanardini (Gigartinales, Rhodophyta) collected from Kyaikkhami and Setse coastal areas, Mon State, Myanmar
}

\begin{abstract}
Liberated tetraspores from Catenella nipae collected from Kyaikkhami (Lat. $16^{\circ} 05^{\prime} \mathrm{N}$,

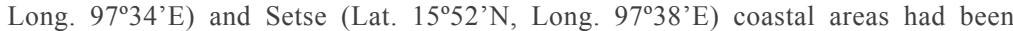
cultured under the laboratory conditions to investigate the germination pattern of this species based on the early stages of cell divisions and development of tetraspores in culture. In the tetraspores germination of $C$. nipae, primary rhizoid developed from lower cell after second cell division during $2 \mathrm{~d}$ in culture. After 5-10 days, tetraspore germlings continued cell divisions from 5 to 18 cells and the rhizoid cells divided into $2-4$ cells reaching a length of $10-150 \mu \mathrm{m}$. The $15 \mathrm{~d}$ old germlings were observed with several cell divisions and produced another rhizoid. The initial of erect blade was observed when the lengths of rhizoids were $800 \mu \mathrm{m}$ during the experimental period of 1 month. In addition, effects of salinity and medium on spore germination were briefly discussed.
\end{abstract}

Keywords: Catenella nipae, Gigartinales, Kyaikkhami and Setse, laboratory culture, Myanmar, Rhodophyta, tetraspore germination
Volume 7 Issue 3 - 2018

\author{
Mya Kyawt Wai \\ Department of Marine Science, Mawlamyine University, \\ Myanmar
}

Correspondence: Mya Kyawt Wai, Lecturer, Department of Marine Science, Mawlamyine University, Myanmar, Emailmrakyawtwai@gmail.com

Received: June 18,2018 | Published: June 29, 2018

\section{Introduction}

The genus Catenella (Rhodophyta, Gigartinales) is the most widespread species throughout the tropic and subtropic regions of the world. ${ }^{1}$ There are only 5 species of genus Catenella recorded around the world, viz., C. caespitosa (Withering) Irvine, C. fusiformis (Agardh) Skottsberg, C. impudica (Montagne) Agardh, C. nipae Zanardini, and C. subumbellata Tseng. Among these species, $C$. caespitosa, C. impudica and $C$. nipae were recorded from the coastal regions of Myanmar. ${ }^{1-8}$ C. nipae is one of the most abundant species of Kyaikkhami and Setse coastal areas (Myanmar). C. nipae abundantly grow on the rocks and pneumatophores of mangroves especially during raining season. C. nipae, commonly called Kyaukpwint in Myanmar, is commercially important species because it is traditionally eaten as salads mixing with other vegetables and can be utilized for carrageenan extraction. ${ }^{5,9}$

Concerning the culture studies of present species, Kyi Shwe ${ }^{10}$ firstly studied the habit field culture of C. nipae. Consenquently, the life history of $C$. nipae was carried out in laboratory culture by Aung Myint. ${ }^{11} \mathrm{He}$ concluded that the genus Catenella has a life history of Polysiphonia type in which this species undergoes alternation of isomorphic tetrasporophyte and gametophyte with the carposporophyte occurring on the female gametophyte. Moreover, Myint Than ${ }^{4}$ also studied the effect of environmental factors on spore germination, thallus growth and reproduction of Catenella species. It was the first which gave details to germination of spores in different salinity, light quality, standard culture media and temperature.

Soe-Htun, Htay Htay Mon and Win Latt ${ }^{12}$ studied the relative abundance of vegetative and reproductive phases of $C$. nipae in the mangrove swamps at Setse. They described the different occurrence of $C$. nipae during the monsoon to the out of monsoon seasons by counting the vegetative and reproductive plants in those seasons. They concluded that the reproductive plants were more common than the vegetative plants in premonsoon and peak occurrence of vegetative growth was observed in the post-monsoon season. According to Soe-Htun ${ }^{5}$ Catenella was an economically important seaweed, and experimental cultivations on Catenella and Gracilaria were carried out to produce food, agar-agar and carrageenan.

In the present study, liberated tetraspores from $C$. nipae collected from Kyaikkhami and Setse coastal areas were cultured to observe spore germination under the laboratory conditions. The objective of this study was to know germination patterns of $C$. nipae.

\section{Materials and Methods}

Biological materials of the present study were collected from the Kyaikkhami (Lat. $16^{\circ} 05^{\prime} \mathrm{N}$, Long. $97^{\circ} 34^{\prime} \mathrm{E}$ ) and Setse (Lat. $15^{\circ} 52^{\prime} \mathrm{N}$, Long. $97^{\circ} 38^{\prime} \mathrm{E}$ ) coastal areas (Thanbyuzayat Township, Mon State, Myanmar). The materials kept in an ice-box were brought to the laboratory at Mawlamyine University for the observation. The cultured apparatus such as Petri dishes, glass slides, cover slips, and forceps were washed with tap water and then they were sterilized again with boiling water. Sterile seawater was adjusted to get salinity 20 by refretometer. And then, PES culture medium ${ }^{13}$ was prepared for both spore liberation and germination. Furthermore, Germenium dioxide $\left(\mathrm{GeO}_{2}\right)$ was added to the medium to suppress growth of diatoms. The excise fertile branches were washed several times in sterile seawater using artist brushes. After being carefully washed with filtered and sterilized seawater, the plants packed with tissue paper were kept under the dark condition for overnight. At the next morning, the plants were placed in Petri dishes $(60 \mathrm{mmx} 13 \mathrm{~mm})$ filled 
with prepared culture medium. These Petri dishes together with cover slips were placed under the white light fluorescent tube in laboratory for spores liberation and settlement.

Cover slips with settled tetraspores were placed in each Petri dish containing $20 \mathrm{ml}$ of culture medium at room temperature. The numbers of cell divisions were recorded and sizes of spores and germlings were measured under the compound microscope using ocular meter in 3 days interval. The developmental stages of tetraspore germlings were photographed by digital camera, processing with Adobe Photoshop 7.0. The medium was changed in 5 days interval. Culture studies were repeated three times. This study followed the classification system of Womersely. ${ }^{14}$

\section{Results and discussion}

\section{General morphology of Catenella nipae Zanardini}

Phylum: Rhodophyta

Class: Florideophyceae

Order: Gigartinales

Family: Caulacanthaceae

Genus: Catenella Greville

Species: C. nipae Zanardini

\section{Description}

Plants dark brown to purple, segmented, forming a decumbent patches with creeping and erect branches, $2-3 \mathrm{~cm}$ high, irregularly dito trichotomuosly branched (Figure 2), terete to strongly compressed segments, up to $6 \mathrm{~mm}$ long and about $2 \mathrm{~mm}$ wide, with constricted nodes; prostrate portion attached to the substratum by haptera developing from the tip of branches; compressed segments, up to $6 \mathrm{~mm}$ long and about $2 \mathrm{~mm}$ wide, with constricted nodes; prostrate portion attached to the substratum by haptera developing from the tip of branches; haptera produce new segments subterminally. In transverse section, segments composed of loosely interlacing and anastomosing medulla filaments that originating from the cental axis; medulla filaments moniliform dichotomously branched and towards the periphery forming a compact cortex. Tetrasporangia scattered in the cortex of segments, ovoid, 40-70 $\mu \mathrm{m}$ long and 20-30 $\mu \mathrm{m}$ in diameter (Figure 3).

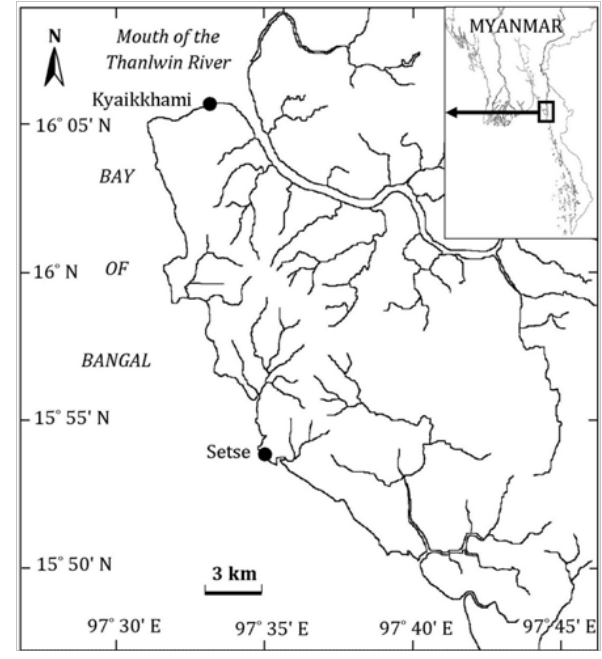

Figure I Map showing the collection sites of Catenella nipae Zanardini.

\section{Tetraspores germination of Catenella nipae Zanardini}

Liberated tetraspores were reddish brown in color and globular, measuring $50-60 \mu \mathrm{m}$ in diameter (Figure 4). Liberated tetraspores from tetrasporangia had attached to the substrate within $24 \mathrm{~h}$. The first division of tetraspores formed by transverse cell wall forming 2 unequal cells during a few hours after they had attached (Figure 5). After that, the second division occurred to divide and produced 2-3 cells during $2 \mathrm{~d}$ in cultivation (Figure 6). Consequently, $2 \mathrm{~d}$ germlings gave rise to an initial of rhizoid, $10 \mu \mathrm{m}$ in length, forming the 4 cells division (Figure 7). After 5 d, 5-10 cells were observed. The rhizoid cells also divided into 2-3 cells reaching a length of $45 \mu \mathrm{m}$ (Figures 8-10). After $10 \mathrm{~d}$, tetrasporeling divided into 15-18 cells. The rhizoid produced 4 cells and reached a length of $150 \mu \mathrm{m}$ (Figure 11). After 15 days, germlings continued to cell division and produced another rhizoid (Figure 12)(Figure13). At this time, the diameters of tetraspores were $70-80 \mu \mathrm{m}$ while the rhizoids reached to $200 \mu \mathrm{m}$ in length and $13 \mu \mathrm{m}$ in width. The initial of erect blade, $130 \mu \mathrm{m}$ in diameter, was observed while the length of rhizoid was $800 \mu \mathrm{m}$ during 1 month in culture (Figure 14) (Figure15).

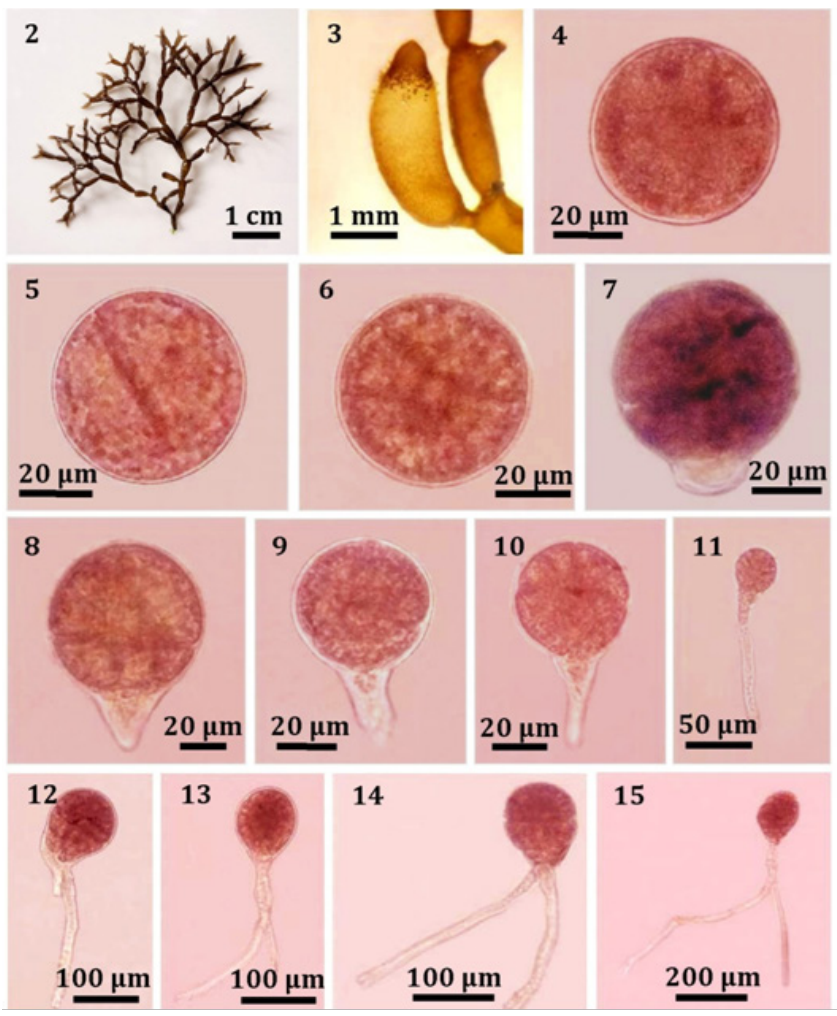

Figures 2-I 5 Tetraspores germination of C. nipae. (2) Mature female plant with tetrasporangia. (3) Mature tetrasporangia. (4) Released tetraspore. (5) The first cell division of tetraspores showing unequal 2 cells (after 24 h). (6) The second cell division of tetraspore germling showing 3-4 cells ( $2 \mathrm{~d}$ old). (7) Tetrasporeling consisting of 3-4 cells with initial of rhizoidal cell ( 2 d old). (8-10) Germlings consisting of $5-10$ cells with 2-3 rhizoidal cells ( $5 \mathrm{~d}$ old). (I I) Germling consisting of I 5 - 18 cells with 4 rhizoidal cells (10 d old). (12-13) Germlings consisting of several cells with developed rhizoids (I5 d old). (14-I5) Germlings consisting of several cells with well-developed rhizoids (I mo. old). 
Catenella nipae were found abundantly at the intertidal zone of Kyaikkhami and Setse coastal areas in monsoon season. However, mature tetrasporangial plants mostly found in Setse while vegetative plants grew copiously in Kyaikkhami. So, mature tetrasporangial plants of $C$. nipae were mainly collected from Setse coastal area for culture studies where the range of salinity was 5-14 in monsoon season. So, released tetraspores from tetrasporangial were firstly cultured with salinities from 5-20 in first experiment under laboratory condition.

In all salinities, the copious quantities of tetraspores were released from tetrasporangial in culture. However, tetraspores become a pale yellow in color after the first division had occurred in salinity variations 5, 10 and 15. In 20 salinity, tetraspores divided to several cell divisions and produced rhizoids. Therefore, liberated tetraspores were cultured only in salinity 20 enriched with PES culture medium. The cultured Petri dishes were placed under the white light fluorescent tube in laboratory at room temperature.

Liberated tetraspores settled to the substratum and gave rise to a first division within a few hours of attachment. After $2 \mathrm{~d}$, germlings showed an initial of rhizoid forming the 4 cells division. After 5-10d, germlings continued cell divisions from 5-18 cells and the rhizoid cells divided into 2-4 cells reaching a length of $10-150 \mu \mathrm{m}$. The 15 $\mathrm{d}$ old plants were observed with several cell divisions and produced another rhizoid. After 1 mo., the germlings reached $130 \mu \mathrm{m}$ in diameter and the length of rhizoids were $800 \mu \mathrm{m}$. Tetraspolings grew well at the salinity 20 under white light in the present study. Likewise, maximum size and cells number of $C$. nipae were observed in the salinity range of 20 to 35 by Myint Than. ${ }^{4}$ She observed that rates of the cell division were significantly higher under yellow and white light conditions than in others as well. She also described that spore germination was slightly higher in Grund medium than those of nonenriched, Erd-schreiber and SWM-3 media during seven days but the germination in Grund medium became similar to those of other media after seven days. Size and number of cell divisions in PES medium seemed to be similar with those of Grund medium.

The germination pattern of this species, the three principle methods observed in the germination of the spore or of the free zygote to form initials of the blade and its holdfast were generally described by Dawson. ${ }^{15}$ Among these principles, Laminaria and Fucus were exemplified for the first type in which primary rhizoids developed from lower cell after first division. In the spores germination of Catenella nipae, the rhizoids developed from basal cell after four cell divisions as well.

\section{Conclusion}

Liberated tetraspores from Catenella nipae were cultured for this study of the spore germination under the laboratory condition. The plants of Catenella nipae abundantly grew along the intertidal region of Kyaikkhami and Setse coastal areas where salinity range was 5-15 in monsoon season. However, spores of this species well developed in salinity 20 and 35 than other salinities, according to the present study and Myint Than ${ }^{4}$ results. So, C. nipae was supposed to be a euryhaline species, although maximum size and cells number occurred in the salinity range between 20 and 35, according to observations from the present study and Myint Than. ${ }^{4}$ In the tetraspores germination of $C$. nipae, two to several cell divisions occurred during 1 month in culture showing a primary rhizoid. The germination pattern of $C$. nipae agreed well with the those of Laminaria and Fucus in which cell divisions produced a primary rhizoid and erect blade. Therefore, it is expected that the results obtained from culture studies on spores germination may be helpful to understand the pattern of germination and to apply biological species concept.

\section{Acknowledgements}

I would like to thank Dr. Aung Myat Kyaw Sein, Rector of Mawlamyine University, Dr. Mie Mie Sein and Dr. San San Aye, Pro-Rectors of Mawlamyine University for their permission to carry out this research work. I would like to express my gratitude to Dr. San Tha Tun, Professor and Head of Department of Marine Science, Mawlamyine University, for his valuable guidance and for providing the departmental facilities. I am very grateful to U SoeHtun, Professor and Head (Retired), Department of Marine Science, and Head of Department of Marine Science, Mawlamyine University and Chairman of Marine Science Association, Myanmar (MSAM), for his guidance during this research work. Thanks are also due to all my respected teachers and colleagues for their encouragement. Finally, my infinite thanks are attributive to my beloved parents for their kind support made to reach the goal of this work.

\section{Conflict of interests}

The author declares that there is no conflict of interest.

\section{References}

1. Guiry MD, Guiry GM. Algae Base version v1.0b1. World-wide electronic publication, National University of Ireland, Galway. 2016.

2. Kyi-Win U. A classified list of the seaweeds of Burma. Proceedings of the Burma Research Congress. 1972;25-29.

3. Kyaw-Soe, Kyi-Win. Seaweeds for utilization. University Translation and Publication Department. Publication.1977;2 (168):502.

4. Myint Than. Experiments on environmental factor requirements of Catenella species. Unpublished M.Sc. Thesis. Department of Marine Biology, Moulmein College. 1982. p.137.

5. Soe-Htun U. The seaweed resources of Myanmar. In: Critchley AT, Ohno M, editors. Seaweed resources of the world. Kanagawa International Fisheries Training Center, Japan International Cooperation Agency (JICA): 1998. 99-105 pp.

6. Soe-Htun, Mya Kyawt Wai, Thida Nyunt, et al. Checklist, distribution and potential utilization of marine algae of Myanmar II. Rhodophyta (Red algae). Jour. Myan. Acad. Arts \& Sc. 2009;7(5):279-305.

7. Hlaing Hlaing Htoon. Studies on the marine algae of Setsè Coastal Areas. Unpublished Master of Research Thesis. Department of Marine Science, Unversity of Mawlamyine. 2009. p. 1-77.

8. Thet Htwe Aung. 2013. Study on the marine benthic algal flora of Kalagauk Island. Unpublished M.Sc. Thesis. Department of Marine Science, Unversity of Mawlamyine. 2013. p. 139.

9. Zaneveld JS. The economic marine algae of the Tropical regions of south and east Asia and their utilization. Spec. Publ. IPFC, 1955;3:55.

10. Kyi Shwe. A study on the habit field culture of Catenella nipae Zanardini (1872). Unpublished M.Sc. Thesis. Department of Marine Biology, Moulmein College. 1973.

11. Aung Myint U. The culture of Catenella nipae Zanardini (1872) under laboratory conditions. Unpublished M.Sc. Thesis. Depatrment of Marine Science, Mawlamyine University, Mawlamyine, Myanmar. 1980.

12. Soe-Htun, Htay Htay Mon, Win Latt. Observations on seasonal variations of vegetative growth and spore formation of Catenella (1983). Burma Research Congress. 1984; p. 5.

13. Provasoli L. Media and prospects for the cultivation of marine algae. In: Waternable A, hattoria, A. editors. Cultures and Collection of Algae, Proc. U.S. Japan Conf. Hakone, 1966, Jap. Soc. Pl Physiol. 1968; 63-75 pp. 
14. Womersley HBS. The marine benthic flora of southern Australia. Rhodophyta. Part IIIA, Bangiophyceae and Florideaphyceae (Acrochaetiales, Nemaliales, Gelidiales, Hildenbrandiales and Gigartinales sensu lato). Womersley HBS editor. 508 pp. Canberra: Australian Biological Resources Study. 1996.
15. Dawson EY. Marine Botany, an introduction. Holt, Rinehart and Winston, Inc. USA. 1966. p. 301 . 